\title{
Kadar Hemoglobin Dan Jumlah Eritrosit Mencit (Mus musculus) Jantan setelah Perlakuan dengan Ekstrak Etanol Daun Nimba (Azadirachta indica)
}

\section{The Haemoglobin concentration and Erythrocyte level of Male Mice (Mus musculus) after Treated with Ethanolic of Neem (Azadirachta indica) Leaf Extract}

\author{
Agung Janika Sitasiwi*, Sri Isdadiyanto \\ Departemen Biologi, Fakultas Sains dan Matematika, Universitas Diponegoro \\ Jl. Prof. Soedarto, SH, Tembalang, Semarang \\ *Email: agssiwi@yahoo.co.id
}

Diterima 2 Juli 2017 / Disetujui 22 Agustus 2017

\begin{abstract}
ABSTRAK
Penelitian ini bertujuan untuk menganalisis kadar hemoglobin $(\mathrm{Hb})$ dan jumlah eritrosit mencit jantan setelah paparan ekstrak ethanol daun Nimba. Hewan uji dalam penelitian ini adalah dua puluh empat ekor mencit jantan dewasa berusia 2.5 bulan dengan bobot badan 25-30 gram, diaklimasi selama 2 minggu, serta dipelihara dalam kondisi kandang dengan kelembaban dan temperatur yang terkontrol. Hewan uji dibagi menjadi 4 kelompok, yaitu P0 sebagai kontrol dengan bahan uji berupa akuades; P1, P2 dan P3 masingmasing diberi ekstrak daun Nimba dengan dosis 8.4; 11.2; $14 \mathrm{mg} / \mathrm{ekor} / \mathrm{hari}$. Perlakuan diberikan secara oral dengan volume $0.3 \mathrm{~mL}$, selama 21 hari. Sampel darah diisolasi langsung dari jantung setelah hewan uji dikorbankan dengan cara pembiusan menggunakan chloroform. Plasma darah ditampung untuk pengukuran kadar $\mathrm{Hb}$ dan jumlah eristrosit. Hasil penelitian menunjukkan bahwa kadar $\mathrm{Hb}$ dan eristrosit kelompok perlakuan lebih rendah dan berbeda bermakna dari kelompok kontrol. Penurunan kadar $\mathrm{Hb}$ hewan uji kelompok perlakuan menunjukkan pola yang sejalan dengan penurunan jumlah eritrosit. Dapat disimpulkan bahwa penggunaan esktrak etanol daun Nimba secara oral selama 21 hari berpotensi mengganggu kesehatan serta menurunkan kebugaran hewan.
\end{abstract}

Kata kunci: hemoglobin, nimba, mencit

\begin{abstract}
This study was conducted to analyze the hemoglobin concentration and the amount of erythrocyte of male mice after exposure with ethanolic Neem leaf extract. The laboratory animals were twenty four male mice aged 2.5 months with 25-30 gram in weight, acclimated for 2 weeks, and kept in a controlled condition cage. The mice were divided into 4 groups, namely P0 as control group, treated with distilled water; P1, P2 and P3 were given Neem leaf extract at dose $8.4 ; 11.2 ; 14 \mathrm{mg} /$ animal/day respectively. The treatment was administered orally with $0.3 \mathrm{~mL}$ in volume, for 21 days. Blood samples were isolated directly from the heart after the mice were sacrificed by using chloroform anaesthesia. Plasma of blood were prepared for $\mathrm{Hb}$ and number of erythrocytes measurement. The results showed that the hemoglobin levels and erythrocytes of treated groups were lower and show a significantly different with the control group. The decrease pattern of $\mathrm{Hb}$ concentration was in line with erythrocytes levels. It could be concluded that the use of ethanolic Neem leaf extract for 21 days potentially affecting the health and decreasing of animal fitness.
\end{abstract}

Keywords: hemoglobin, neem, mice

\section{PENDAHULUAN}

Azadirachta indica merupakan tanaman yang berasal dari India dan tersebar sampai ke Indonesia. Tanaman tersebut dikenal dengan nama lokal Imba, Nimba atau Mimba. Sharma (2013) menyatakan bahwa Nimba banyak dimanfaatkan sebagai tanaman obat. Nimba telah terbukti memiliki efek anti-bakteri, anti-inflamasi, serta anti-diabetes. Auta and Hassan (2016) menyatakan bahwa ekstrak Nimba juga terbukti memiliki 
kemampuan menekan pertumbuhan sel kanker. Ekstrak beberapa bagian pohon nimba, juga telah terbukti memiliki efek anti-malaria, spermisida, anti-tuberkolusis, anti-piretik, anti-virus, antiseboroik, anti-alergi, anti-enzimatik, serta anti jamur.

Suryawanshi (2011) serta Auta and Hassan (2016) menyatakan bahwa nimba mengandung senyawa yang berpotensi sebagai anti-fertilitas, baik pada hewan jantan maupun betina. Tanaman nimba telah digunakan sebagai tanaman yang mempengaruhi kesuburan manusia dan terbukti mampu menginduksi sterilitas secara temporer (Umadevi, 2013). Efek ekstrak beberapa bagian dari tanaman nimba juga diketahui mempengaruhi fungsi reproduksi pada hewan jantan (Assif, 2013). Sharma (2013) menyatakan bahwa ekstrak etanol daun nimba memiliki kemampuan anti-fertilitas, tetapi mekanisme kerja senyawa tersebut belum diketahui dengan pasti. Sitasiwi et al. (2017) membuktikan bahwa paparan ekstrak etanol daun nimba selama 21 hari menyebabkan perubahan level hormon estradiol 17- $\beta$ pada mencit betina.

Joshi et al. (2011) menyatakan bahwa metode baku pengujian suatu senyawa antifertilitas terhadap hewan harus dilakukan dengan tepat karena senyawa yang sama juga berpotensi mengganggu atau mempengaruhi fungsi beberapa organ dalam tubuh. Penggunaan ekstrak nimba sebagai kontrasepsi herbal diduga menyebabkan gangguan pada organ tubuh yang lain, terutama jika dikonsumsi dalam jangka waktu lama dan dosis yang tinggi. Efek samping Nimba juga diduga dapat menyebabkan kerusakan struktur hati dan ginjal (Kupradinun et al. 2012). Umadevi (2013) menyatakan bahwa pengujian potensi antifertilitas dan toksisitas tanaman obat lokal akan memberikan keyakinan yang besar pada pemakai sehingga dapat diterima secara luas oleh pengguna kontrasepsi herbal. Akin-Osanaiye et al. (2015) menyatakan bahwa penggunaan ekstrak nimba sebagai tanaman obat juga tidak diikuti bagaimana pemulihan efek atau resiko keamanan dan toksisitasnya.

De-Oliviera dan Vitoria (2011) serta Bansal et al. (2014) menyatakan bahwa senyawa yang bertanggung jawab untuk efek kontrasepsi ini bisa berupa alkaloid, steroid, triterpenoid, atau flavonoid. Berbagai senyawa tersebut telah diyakini memiliki efek sitotoksik (De-Oliviera dan Vitoria, 2011). Paparan senyawa sitotoksik dapat mempengaruhi pembelahan maupun perkembangan sel dalam tubuh, termasuk sel darah. Hasil penelitian Sitasiwi and Mardiati (2016) menunjukkan bahwa paparan senyawa antifertilitas dalam biji pepaya terbukti mempengaruhi status hematologis mencit betina.

Parameter hematologi adalah parameter yang terkait dengan organ pembentuk darah dan darah (Akin-Osanaiye et al., 2015). Jasper et al. (2012) menyatakan bahwa parameter hematologi, seperti hematokrit, hemoglobin, dan jumlah eritrosit dan sel darah putih, dapat digunakan sebagai indikator toksisitas dan memiliki aplikasi potensial yang luas dalam pemantauan kondisi lingkungan. Pemeriksaan hematologis juga merupakan salah satu metode yang dapat digunakan untuk mendeteksi beberapa perubahan status kesehatan, yang mungkin tidak terlihat dalam pemeriksaan fisik tetapi mempengaruhi kebugaran hewan (Akin-Osanaiye et al., 2015). Etim et al. (2014) menyatakan bahwa parameter hematologis merupakan indikator status fisiologis hewan yang baik karena darah berperan sebagai reflektor patologis terhadap status hewan yang terpapar terhadap racun dan kondisi lainnya.

Berdasar latar belakang di atas, tujuan penelitian ini adalah menganalisis kadar hemoglobin dan eritrosit mencit jantan setelah paparan ekstrak ethanol daun Nimba. Hasil penelitian ini diharapkan memberikan informasi tentang tingkat keamanan penggunaan ekstrak Nimba sebagai senyawa anti-fertilitas terhadap status hematologis mamalia.

\section{METODE PENELITIAN}

\section{Hewan Uji}

Penelitian ini menggunakan 24 ekor mencit jantan dewasa yang berumur 2.5 bulan, dengan bobot berkisar 25-30 g. Sebelum diberi perlakuan dengan bahan uji, mencit diaklimasi pada kondisi laboratorium selama 2 minggu. Pemeliharaan dilakukan dengan menempatkan 
mencit pada kandang pemeliharaan dengan kepadatan 4-5 ekor per kandang. Pakan dan minum hewan uji diberikan secara ad libitum. Pencahayaan, temperatur dan kelembaban kandang pemeliharaan dicatat setiap hari.

\section{Cara Pembuatan ekstrak ethanol daun $A$. Indica}

Daun nimba dikumpulkan dari satu pohon nimba yang terdapat di sekitar kampus FSM UNDIP. Daun yang diperoleh, dicuci bersih dengan air mengalir selanjutnya dikeringkan dengan oven pada suhu $40{ }^{\circ} \mathrm{C}$ selama 10 hari. Daun yang telah kering diketahui dengan cara menimbang selama 3 hari berturut-turut, apabila berat telah konstan selama 3 hari berturut-turut maka daun dianggap telah kering. Daun yang sudah kering dibuat tepung dengan cara menghancurkan dengan blender kemudian diayak. Tepung daun selanjutnya diesktraksi menggunakan ethanol $70 \%$. Hasil akhir ekstraksi ethanol daun nimba berupa serbuk. Ekstrak ethanol daun nimba dibuat sediaan bahan perlakuan sesuai dengan konsentrasi yang telah ditentukan, yaitu 8.4, 11.2 dan $14 \mathrm{mg} /$ ekor/hari (Sitasiwi et al., 2017).

\section{Cara Perlakuan}

Mencit jantan ditimbang sebelum perlakuan dilaksanakan. Mencit dengan bobot badan yang seragam dipilih sebagai hewan uji, ditempatkan pada kandang pemeliharaan dengan kepadatan 3 ekor mencit per kandang. Mencit dibagi menjadi 4 kelompok perlakuan yaitu: P0, kelompok kontrol, hewan uji yang diberi perlakuan akuades; kelompok perlakuan $\mathrm{P} 1, \mathrm{P} 2$ dan $\mathrm{P} 3$, yang diberi perlakuan ekstrak ethanol daun nimba dengan dosis masing-masing $8.4 ; 11.2 ; 14 \mathrm{mg} / \mathrm{ekor} / \mathrm{hari}$. Perlakuan diberikan secara oral menggunakan jarum gavage, dengan volume $0.3 \mathrm{~mL} /$ hewan uji, setiap pagi hari, selama 21 hari berturut-turut. Bobot badan hewan uji diukur setiap 1 minggu sekali, sedangkan konsumsi pakan dan minum diukur setiap hari.

Setelah perlakuan berakhir, hewan uji dipuasakan selama 12 jam. Bobot hewan uji diukur sebelum hewan uji dikorbankan dengan cara anestesi menggunakan chloroform. Darah diisolasi langsung dari bagian jantung, menggunakan syringe dengan ukuran $1 \mathrm{~mL}$ dengan needle No. 23G. Darah yang berhasil ditampung, selanjutnya ditempatkan pada tabung yang mengandung EDTA, selanjutnya disentrifus $3000 \mathrm{rpm}$. Plasma darah dipisahkan dan ditempatkan pada tabung eppendorf untuk analisa kadar $\mathrm{Hb}$ dan eritrosit. Analisa kadar $\mathrm{Hb}$ dan jumlah eritrosit dilakukan di Laboratorium Wahana, Semarang. Efek paparan ekstrak ethanol daun Nimba terhadap kadar $\mathrm{Hb}$ dan eritrosit ditentukan dengan membandingkan kadar $\mathrm{Hb}$ dan eritrosit hewan uji pada kelompok kontrol dan kelompok perlakuan.

\section{Analisis Data}

Data berupa kadar $\mathrm{Hb}$ dan jumlah eritrosit dianalisa dengan ANOVA. Hasil ANOVA menunjukkan perbedaan bermakna maka dilanjutkan dengan uji DMRT pada taraf signifikasi $5 \%$.

\section{HASIL DAN PEMBAHASAN}

Hasil pengamatan terhadap hewan uji selama perlakuan berlangsung menunjukkan terjadi kematian 3 hewan uji. Kematian hewan uji dialami oleh 1 ekor mencit pada kelompok perlakuan P2 dan 2 ekor mencit pada kelompok perlakuan P3. Hal tersebut dapat diartikan bahwa dosis dan lama paparan bahan uji mempengaruhi ketahanan hidup hewan uji.

Hasil pengukuran kadar hemoglobin dan penghitungan jumlah eritrosit disajikan pada Tabel 1. Hasil ANOVA terhadap rerata kadar hemoglobin menunjukkan perbedaan bermakna $(\mathrm{p}<0.05)$ antara hewan uji pada kelompok kontrol $(14,26 \pm 0.671)$ dan hewan uji pada kelompok perlakuan. Hasil uji lanjut DMRT dengan taraf signifikansi $0.5 \%$ menunjukkan bahwa rerata kadar hemoglobin pada kelompok perlakuan P1 $(12,42 \pm 0.234)$ tidak berbeda bermakna ( $p>0.05)$ dengan kelompok perlakuan P2 $(12,25 \pm 0.862)$ maupun P3 (11.95 \pm 0.457$)$. Hal tersebut juga menunjukkan bahwa dosis perlakuan P3 (14 mg/ekor/hari) memberikan penurunan kadar $\mathrm{Hb}$ yang paling besar. 
Tabel 1. juga menunjukkan bahwa hasil ANOVA terhadap rerata jumlah eritrosit menunjukkan perbedaan bermakna $(\mathrm{p}<0.05)$ antara hewan uji pada hewan uji kelompok kontrol $(8.83 \pm 0.662)$ dan kelompok perlakuan. Hasil uji lanjut DMRT dengan taraf signifikansi $0.5 \%$ menunjukkan perbedaan tidak bermakna $(\mathrm{p}>0.05)$ pada jumlah eritrosit pada hewan uji kelompok perlakuan P1 (7.15 \pm 0.567$)$ dan P2 $(7.00 \pm 0.453)$, tetapi menunjukkan perbedaan bermakna $(\mathrm{p}<0.05)$ dengan hewan uji kelompok perlakuan P3 $(5.83 \pm 0.239)$.

Tabel 1. Rerata kadar hemoglobin dan jumlah eritrosit mencit jantan setelah perlakuan dengan ekstrak etanol daun Nimba

\begin{tabular}{lcc}
\hline & Hb $(\mathrm{g} / \mathrm{dL})$ & Eritrosit $\left(\mathrm{x} 10^{6}\right)$ \\
& $\mathrm{X} \pm \mathrm{SD}$ & $\mathrm{X} \pm \mathrm{SD}$ \\
\hline P0 $(\mathrm{n}=6)$ & $14.26^{\mathrm{a}} \pm 0.671$ & $8.83^{\mathrm{a}} \pm 0.662$ \\
P1 $(\mathrm{n}=6)$ & $12.42^{\mathrm{b}} \pm 0.234$ & $7.15^{\mathrm{b}} \pm 0.567$ \\
P2 $(\mathrm{n}=5)$ & $12.25^{\mathrm{b}} \pm 0.862$ & $7.00^{\mathrm{b}} \pm 0.453$ \\
P3 $(\mathrm{n}=4)$ & $11.95^{\mathrm{b}} \pm 0.457$ & $5.83^{\mathrm{c}} \pm 0.239$ \\
\hline
\end{tabular}

Keterangan: Hasil penelitian disajikan dalam bentuk rerata (X) dan simpangan baku (SD) Angka yang diikuti superksrip yang sama pada kolom yang sama menunjukkan perbedaan tidak bermakna pada taraf signifikansi $5 \%$. $\mathrm{Hb}$ : Hemoglobin.

Penelitian ini hanya mengamati kadar hemoglobin dan jumlah eritrosit hewan uji setelah paparan ekstrak etanol daun nimba. Hasil penelitian menunjukkan bahwa kadar hemoglobin dan jumlah eritrosit hewan uji dipengaruhi oleh paparan ekstrak etanol daun Nimba selama 21 hari.
Hasil pengukuran kadar hemoglobin juga menunjukkan pola yang sama dengan jumlah eritrosit hewan uji, semakin besar dosis maka semakin rendah kadar hemoglobin dan jumlah eritrosit, disajikan pada Gambar 1.

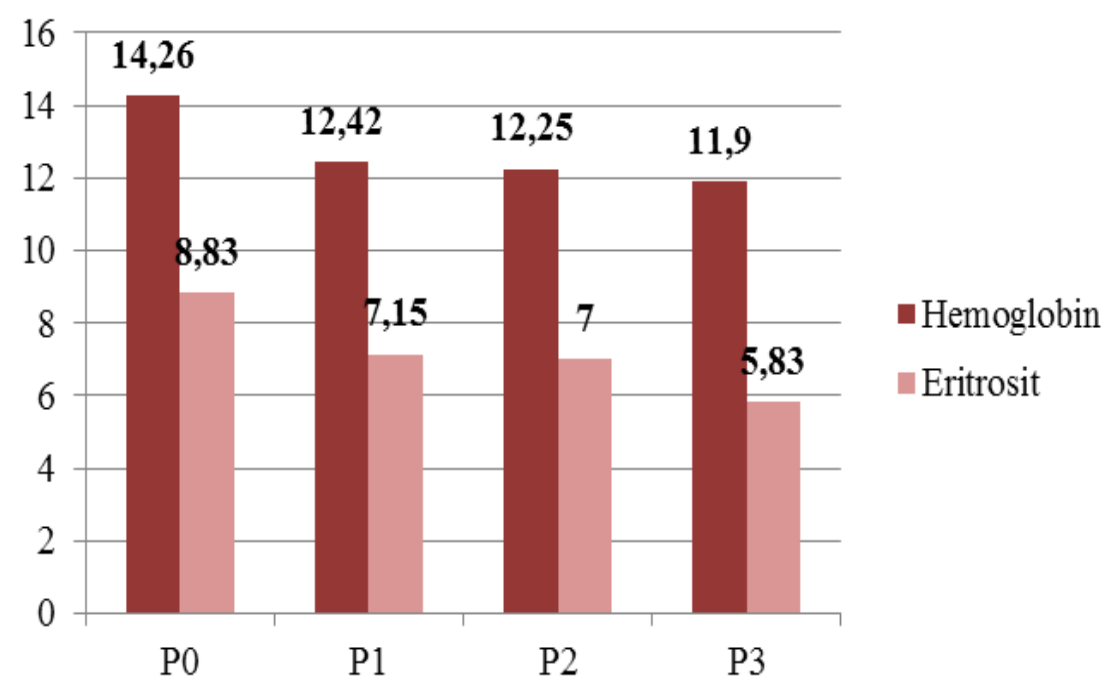

Gambar 1. Komparasi kadar hemoglobin (g/dL) dan jumlah eritrosit $\left(\times 10^{6}\right)$ mencit jantan setelah pemberian ekstrak etanol daun Nimba selama 21 hari

Etim et al. (2014) menyatakan bahwa hemoglobin dan eristrosit merupakan komponen hematologi. Kedua komponen tersebut dapat digunakan sebagai sarana untuk memantau toksisitas suatu bahan terutama yang mempengaruhi darah serta status kesehatan hewan. Eritrosit atau sel darah merah berfungsi sebagai pembawa hemoglobin. Hemoglobin inilah yang bereaksi dengan oksigen yang dibawa dalam darah untuk membentuk oksihemoglobin selama 
respirasi (Opara et al., 2010). Hasil penelitian Benkovic et al. (2012) menunjukkan bahwa konsentrasi haemoglobin dan jumlah sel darah merah pada mencit yang normal adalah 12,79 $(\mathrm{g} / \mathrm{dL})$ untuk kadar hemolgobin dan 8,77 $\left(\mathrm{x} 10^{6}\right)$ untuk jumlah eritrosit. Hasil penelitian AkinOsanaiye et al. (2015) menunjukkan bahwa mencit kelompok kontrol memiliki kadar hemoglobin 15,90 (g/dL). Hasil penelitian ini menunjukkan bahwa kadar hemoglobin dan jumlah eritrosit hewan uji kelompok kontrol berada pada nilai normal. Berdasarkan hasil tersebut, dapat dipastikan bahwa perbedaan rerata antara kelompok kontrol dan perlakuan disebabkan oleh bahan uji yang diberikan.

Ekstraksi bahan uji dalam penelitian ini dilakukan menggunakan etanol. Samsudin (2011) menyatakan bahwa etanol dapat melarutkan zat yang memiliki polaritas rendah sampai tinggi. Etanol juga menghasilkan bahan aktif yang optimal dan tidak beracun. Ekstraksi etanol juga memungkinkan alkaloid, saponin, serta tanin dapat larut (Bansal et al., 2014). Bahan aktif yang terlarut melalui ekstraksi etanol diduga menyebabkan perbedaan respon hewan uji, baik antara kelompok kontrol dengan kelompok perlakuan ataupun hewan uji antar kelompok perlakuan. Francis et al. (2002) menyatakan bahwa saponin merupakan senyawa antifertilitas yang mempunyai pengaruh negatif terhadap reproduksi ternak, seperti aborsi atau kematian, menyebabkan steril dan penghentian proses kebuntingan. Bottger and Melzig (2013) menyatakan bahwa saponin beraksi dengan cara mengganggu stabilitas membran sel. Gangguan membran sel yang disebabkan oleh keberadaan saponin dalam bahan uji diduga menjadi penyebab penurunan jumlah eritrosit dan kadar hemoglobin pada hewan uji kelompok perlakuan.

Setyowati dkk. (2015) menyatakan bahwa senyawa lain yang dapat larut dengan pelarut etanol adalah tanin. Tanin merupakan metabolit sekunder yang dapat menghambat pertumbuhan tumor. Tanin mempunyai efek anti mitotik dan bersifat sitotoksik pada sel yang mengalami pembelahan cepat. Sifat sitotoksik yang dimiliki oleh tanin diduga menyebabkan penurunan jumlah eristrosit pada hewan uji kelompok perlakuan, seperti yang terjadi dalam penelitian ini.

Subashree et al. (2014) menyatakan bahwa sel darah merah berperan dalam pengangkutan oksigen dan karbon dioksida di dalam tubuh. Gangguan fungsi sel darah merah sebagai akibat paparan bahan uji dalam ekstrak etanol daun Nimba, diduga menjadi penyebab gangguan distribusi oksigen dan karbondioksida pada hewan uji sehingga menyebabkan kematian hewan uji pada kelompok perlakuan P2 dan P3. Kematian yang terjadi pada hewan uji pada kelompok perlakuan P2 dan P3 juga diduga terjadi karena semakin tinggi dosis yang diberikan akan menyebabkan semakin tingginya senyawa aktif yang bersifat toksik terhadap hewan uji.

\section{KESIMPULAN}

Hasil penelitian menunjukkan bahwa kadar hemoglobin dan jumlah eritrosit mengalami penurunan yang berbeda bermakna sehingga dapat disimpulkan bahwa penggunaan esktrak etanol daun Nimba secara oral selama 21 hari berpotensi mengganggu kesehatan serta menurunkan kebugaran hewan.

\section{UCAPAN TERIMA KASIH}

Peneliti mengucapkan terima kasih kepada Dekan Fakultas Sain dan Matematika atas dukungan dana yang diberikan melalui proyek PNBP Fakultas Sains dan Matematika dengan Nomor Kontrak: 1643B/UN7.5.8/PP/2017 Tanggal 3 April 2017.

\section{DAFTAR PUSTAKA}

Akin-Osanaiye, B. C., A.J.Nok, E. Amlabu, E. Haruna, 2015. Assessment of Changed in Serum Haematological Parameters in the Plasmodium berghei Infected Albino Mice Treated with Neem (Azadirachta indica) Extracts. International Journal of Chemical and Biomolecular Science. 1(3): 148-152.

Asif M., 2013. A Review on Spermicidal Activities of Azadirachta indica. Journal of 
Pharmacognosy and Phytochemistry. 1(5): 61-79.

Auta, T. and A.T. Hassan, 2016. Reproductive toxicity of aqueous wood-ash extract of Azadirachta indica (Neem) on male albino mice. Asian Pacific Journal of Reproduction. $\mathrm{X}(\mathrm{x})$ : 1-5.

Bansal P, R. Bansal R, V. Gupta, 2010. Antifertility effects of Azadirachta indica (Neem) - A Review. Annals of Biological Research. 1(2): 108-113.

Benkovic, V., D. Dikic, T. Grgorinic, M. Mladinic, D.Z. Eljezic, 2012. Haematology and Blood Chemistry Changes in Mice Treated with Terbuthylazine and its Formulation Radazin TZ-50. Bull Environ Contam Toxicol. 89: 955-959.

Bottger, S. and M.F. Melzig, 2013. The influence of saponins on cell membrane cholesterol. $J$. Med. Chem. 21: 7118-7124.

DeOliveira, J.G., A.P. Vitoria, 2011. Papaya: Nutritional and pharmacological characterization, and quality loss due to physiological disorders. An overview. Food Research International 44: 1306-1313.

Etim, N.N., M.E. Williams, U. Akpabio, E.E.A. Offiong, 2014. Haematological Parameters and Factors Affecting Their Values. Agricultural Science. 2(1): 37-47.

Francis, G., Z. Kerem, H.P.S. Makkar, K. Becker. 2002. The Biological action of saponins in animal system: review. British Journal of Nutrition. 88: 587-605.

Jasper, R., G. O. Locatelli, C. Pilati, C. Locatelli, 2012. Evaluation of biochemical, hematological and oxidative parameters in mice exposed to the herbicide glyphosateRoundup. Interdiscip Toxicol. 5(3): 133140.

Joshi, M., K. Gaonkar, S. Mangoankar, S. Satarkar, 2011. Pharmacological investigation of Areca catechu extracts for evaluation of learning, memory and behavior in rats. International Current Pharmaceutical Journal. 1(6): 128-132.
Kupradinun, P., A. Tepsuwan, N. Tanthasri, N. Meesiripan, S. Tunsakul, W. Tompat, Y. Jarratwisautpom, W.R. Kusamran, 2012. Toxicity Testing of Flowers of Neem Tree (Azadirachta indica A. Juss). Thai J. Vet. Med. 40(1): 47-55.

Opara, M.N., N. Udevi, and I.C. Okoli, 2010. Haematological Parameters And Blood Chemistry Of Apparently Healthy West African Dwarf (Wad) Goats In Owerri, South Eastern Nigeria. New York Science Journal. 3(8): 68.

Samsudin, 2011, Biosintesa Dan Cara Kerja Azadirachtin Sebagai Bahan Aktif Insektisida Nabati, Balai Penelitian Tanaman Rempah dan Aneka Tanaman Industri, Sukabumi.

Setyowati, E.A.W., D.R.S. Ariani, Ashadi, B. Mulyani, A. Hidayat. 2015. Aktivitas Antifertilitas Kontrasepsi dari Kulit Durian (Durio zibethinus Murr.) Varietas Petruk. program Studi Pendidikan Kimia Jurusan FMIPA FKIP UNS, Surakarta.

Sharma, R.K., A.K. Goyal, R.A. Bhat, 2013. Antifertility of Plants Extracts on Female Reproduction: A Review. IJBS. 3(3): 493514.

Sitasiwi, A.J. dan S.M. Mardiati, 2016. Effect of Carica papaya Seeds Water Extract on Haematological Parameters of mice. Proceeding $6^{\text {th }}$ ISNPINSA.

Sitasiwi, A.J., S. Isdadiyanto, S.M. Mardiati, 2017. The estradiol 17- $\beta$ concentration in mice after treated with ethanolic leaf extract of Azadirachta indica (neem). Proceeding of International Conference on Global Resource and Conservation. AIP Conference Proceeding. doi: 10.1063/1.4983425.

Subashree, A,R., P.J. Phrameswari, B. Shanti, C. Revathy, B.O. Parijatham, 2014. The reference intervals for the healthy adult population of Chennai, Southern India. Journal of Clinical and Diagnostic research. 6(10): 1675-1680. 
Kadar Hemoglobin Dan Jumlah Eritrosit Mencit (Mus musculus) Jantan setelah Perlakuan dengan Ekstrak Etanol Daun Nimba (Azadirachta indica)

Suryawanshi, J.A.S. 2011. Neem - natural contraceptive for male and female-an overview. International Journal of Biomolecules and Biomedicine. 1(2): 1-6.

Umadevi, K., P.K. Sampath Khumar, D. Bhownik, S. Duraivel, 2013. Medicinal Plants with Potential Antifertility Activities. Journal of Medicinal Plants Studies. 1(1): 26-33. 